\title{
Albumin To Creatinine Protein Ratio Measurement
}

National Cancer Institute

\section{Source}

National Cancer Institute. Albumin To Creatinine Protein Ratio Measurement. NCI

Thesaurus. Code C74761.

The determination of the ratio of albumin compared to creatinine protein present in a urine sample. The measurement may be expressed as a ratio or percentage. 